Syntax Literate: Jurnal Ilmiah Indonesia p-ISSN: 2541-0849

e-ISSN: 2548-1398

Vol. 6, No. 2, Februari 2021

\title{
PERILAKU HATE SPEECH DI MEDIA SOSIAL DENGAN POLA ASUH ORANG TUA DI KALANGAN REMAJA PENGGUNA MEDIA SOSIAL
}

\section{Endah Sari Purbaningsih}

Sekolah Tinggi Ilmu Kesehatan (STIKes) Mahardika Cirebon, Jawa Barat, Indonesia

Email: endahsari155@gmail.com

\section{Abstract}

Social media is used as a means of self-existence by most teenagers at this time. Social media makes it easy for teens to connect with one another. This raises a problem in the form of the fusion of private space with the public space of its users. This condition can support criminal acts on social media, one of which is hate speech or hate speech. The purpose of this study was to see the relationship between hate speech behavior on social media and parenting styles among adolescent social media users. The design of this research is descriptive analytic using a survey method with a correlational approach. The sampling technique used non probability sampling, namely accidental sampling. The number of samples obtained was 228 teenagers who are active on social media. The results showed that the level of tendency of adolescents to behave with hate speech on social media mostly had the type of authoritarian parenting as many as 121 respondents (53.1\%), then those who had the type of democratic parenting were 57 respondents (25\%), and those who had the type of pattern. permissive foster care as many as 50 respondents (21.9\%). The results of statistical tests using the Chi-Square test by looking at the Pearson ChiSquare value obtained $p=0.000(p \leq 0.05)$ then $\mathrm{HO}=$ rejected, meaning that there is a relationship between hate speech behavior on social media with parenting styles among adolescent users. social media.

Keywords: social media; adolescent; hate speech, parenting.

\section{Abstract}

Media sosial dijadikan sebagai sarana eksistensi diri oleh sebagian besar remaja pada masa ini. Media sosial memudahkan remaja untuk saling terhubung satu sama lain. Hal tersebut menimbulkan permasalahan berupa peleburan ruang privat dengan ruang publik para penggunanya. Kondisi tersebut memungkinkan terjadinya perbuatan kejahatan di media sosial, salah satunya adalah hate speech atau ujaran kebencian. Tujuan penelitian ini untuk mengetahui hubungan perilaku hate speech di media sosial dengan pola asuh orang tua di kalangan remaja pengguna media sosial. Jenis atau rancangan penelitian ini adalah deskriptif analitik menggunakan metode survey dengan pendekatan korelasional. Teknik pengambilan sampel menggunakan non probability sampling, yaitu accidental sampling. Jumlah sampel yang didapatkan sebanyak 228 orang remaja yang aktif di media sosial. Hasil penelitian menunjukan bahwa tingkat kecenderungan remaja berperilaku hate speech di media sosial sebagian besar memiliki jenis pola asuh otoriter sebanyak 121 responden $(53,1 \%)$, kemudian yang memiliki jenis pola asuh demokratis sebanyak 57 responden $(25 \%)$, 
dan yang memiliki jenis pola asuh permisif sebanyak 50 responden $(21,9 \%)$. Hasil uji statistik menggunakan uji Chi-Square dengan melihat nilai Pearson Chi-Square didapatkan $\mathrm{p}=0,000(\mathrm{p} \leq 0,05)$ maka $\mathrm{H} 0=$ di tolak artinya terdapat hubungan antara perilaku hate speech di media sosial dengan pola asuh orang tua di kalangan remaja pengguna media sosial.

Kata Kunci: media sosial; remaja; perilaku hate speech; pola asuh

\section{Coresponden Author}

Email: endahsari155@gmail.com Artikel dengan akses terbuka dibawah lisensi

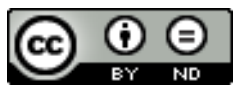

\section{Pendahuluan}

Remaja (adolescent) memiliki arti tumbuh kearah kematangan. Remaja adalah seseorang yang memiliki rentang usia 10-24 tahun. Remaja memiliki artian yang sangat luas dari segi fisik, psikologis, dan sosial. Secara psikologis remaja adalah usia seseorang yang memasuki proses menuju usia dewasa. Masa remaja merupakan masa pencarian jati diri dimana seorang remaja melakukan segala cara agar dirinya diakui sebagai suatu individu dengan mencoba hal-hal baru (World Health Organization (WHO), 2014).

Menurut (World Health Organization (WHO), 2014) data demografi dunia menunjukan bahwa penduduk di dunia populasi terbesar merupakan remaja. Populasi remaja di dunia berjumlah 1,2 miliar atau $18 \%$ dari jumlah penduduk dunia. Data Badan Kependudukan dan Keluarga Berencana Nasional (BKKBN) tahun 2016, penduduk remaja berusia 10-24 tahun berjumlah 66,3 juta jiwa dari total penduduk sebesar 258,7 juta sehingga satu di antara empat penduduk adalah remaja. Jumlah yang cukup besar tersebut merupakan potensi yang memerlukan pengelolaan secara terencana, terstruktur dan sistematis agar dapat bermanfaat menjadi modal pembangunan di masa yang akan datang.

Remaja lebih dikenal dengan sebutan milenial. Di era digital ini banyak remaja yang mencoba mengeksistensikan dirinya melalui media sosial. Sebagian besar remaja sekarang menggunakan media sosial sebagai media untuk eksistensi diri. Media sosial merupakan sekumpulan aplikasi berbasis internet, beralaskan pada ideologi dan teknologi web 2.0 sehingga memungkinkan penciptaan dan pertukaran konten oleh penggunanya. Pada era digital, tidak ada lagi batas ruang dan waktu untuk memperoleh informasi. Media sosial memudahkan remaja untuk saling terhubung satu sama lain. Bahkan, mereka lebih akrab dengan dunia digital dibandingkan dengan dunia nyata. Waktu rerata yang dihabiskan setiap individu untuk menggunakan media sosial semakin meningkat dari tahun ke tahun. Hampir dua pertiga masyarakat dewasa di Amerika menggunakan lebih dari satu media sosial. Dewasa muda (18-29 tahun) memiliki ratarata pengguna media sosial terbesar $(90 \%)$, dan grup usia lain (remaja dan dewasa) juga mengalami peningkatan jumlah yang signifikan (Akbar, Pilcher, \& Perrin, 2015). 
Hasil dari survei yang dilakukan oleh Kementerian Komunikasi dan Informasi (Kominfo) tahun 2015, menunjukkan lima media sosial terpopuler di Indonesia, yaitu Facebook (65.000.000 pengguna), Twitter (19.500.000 pengguna), Google+ (3.400.000 pengguna), LinkedIn (1.000.000 pengguna), dan Path (700.000 pengguna). Permasalahan yang timbul pada penggunaan media sosial antara lain berupa peleburan ruang privat dengan ruang publik para penggunanya. Hal ini mengakibatkan pergeseran budaya berupa pengguna tidak lagi segan meng-upload segala kegiatan pribadinya untuk disampaikan kepada teman atau kolega melalui akun media sosial dalam membentuk identitas diri mereka. Berdasarkan fenomena yang ada, hal ini memungkinkan terjadinya perbuatan kejahatan di media sosial. Perbuatan kejahatan yang terjadi di kalangan pengguna media sosial saat ini salah satunya yaitu hate speech atau ujaran kebencian. Council of Europe hatespeech (Judhita, 2017) memahami hate speech sebagai semua bentuk ekspresi yang menyebar, menghasut, mempromosikan atau membenarkan kebencian rasial, xenophobia, anti-semitisme atau lainnya dalam bentuk kebencian berdasarkan intoleransi.

Hate speech sendiri merupakan tindakan komunikasi yang dilakukan oleh suatu individu atau kelompok dalam bentuk provokasi, hasutan, ataupun hinaan kepada individu atau kelompok yang lain dalam hal berbagai aspek seperti ras, warna kulit, gender, cacat, orientasi seksual, kewarganegaraan, agama, perbedaan perspektif dan lain-lain. Hate speech dapat dilakukan melalui berbagai media antara lain yaitu melalui orasi kegiatan kampanye, spanduk atau banner, jejaring media sosial, penyampaian pendapat dimuka umum (demonstrasi), ceramah keagamaan, media masa cetak maupun elektronik, dan pamflet (Manusia, 2015).

Berdasarkan data yang dihimpun dari Kominfo dan Mabes Polri tindak kasus hate speech atau ujaran kebencian yang dilakukan para remaja tersebut yang terjadi di media sosisal periode Januari-Juni tahun 2019 mengalami peningkatan sebanyak 50\% dibandingkan sepanjang tahun 2018. Perkara tindak pidana ujaran kebencian yang ditangani Polri sekitar 101 perkara. Sementara itu, sepanjang tahun 2018 hanya ada sekitar 255 perkara ujaran kebencian selama setahun penuh.

Faktor-faktor yang mempengaruhi perilaku hate speech pada remaja di media sosial yaitu faktor psikologis atau kejiwaan pelaku yaitu daya emosional yang tinggi, serta faktor sarana, fasilitas dan kemajuan teknologi. Dampak yang ditimbulkan dari ujaran kebencian yang diterima oleh korban yaitu dampak psikologis yang berupa emosi negatif dan emosi positif. Emosi negatif tersebut diantaranya merasa marah, tidak nyaman, sedih, tertekan, malu, takut, tidak percaya diri, dan sakit hati. Sedangkan emosi positif yaitu merasa semangat (Astuti, 2019).

Menurut Kementerian Pendidikan dan Kebudayaan tahun 2016, perkembangan teknologi yang pesat membuat sulit untuk mencegah seseorang tidak memiliki akun media sosial. Keluarga berperan penting dalam mengajarkan bagaimana menggunakan media sosial yang bijak terutama terhadap remaja. Orang tua perlu mengajarkan mengenai konten apa saja yang bisa diunggah yang tidak membahayakan diri mereka sendiri. Hampir semua pendidikan bermula dari pendidikan keluarga termasuk 
pendidikan dalam menggunakan internet yang bijak. Intinya bukan mencegah seseorang memiliki media sosial, tetapi dengan mengajarkan bagaimana menggunakan media sosial secara tepat. Keluarga khususnya orang tua dapat memahami perkembangan teknologi pada zaman sekarang, dan juga sosial media yang saat ini telah banyak digunakan remaja. Oleh karena itu banyak remaja yang terpengaruh dengan sosial media dan banyak menghabiskan waktunya hanya untuk bermain sosial media, bahkan bisa berjam-jam. Hal ini jika dibiarkan terus menerus akan menyebabkan anak kurang bisa untuk bersosialisasi pada masyarakat.

Penelitian yang dilakukan oleh (Permono, 2013), menunjukkan ada hubungan peran orang tua dalam mengoptimalisasi tumbuh kembang anak untuk membangun karakter anak. Penelitian lainnya ini didukung oleh (Briawan \& Herawati, 2008) peran stimulasi orang tua sangat berarti bagi perkembangan anak, dengan demikian peran orang tua memiliki pengaruh terhadap perkembangan anak khususnya remaja.

Orang tua saat ini diasosiasikan sebagai digital immigrant atau penduduk pendatang yang masih berusaha beradaptasi di dunia digital sebagai salah satu hasil dari perkembangan teknologi yang baru, orang tua sebagai digital immigrant dituntut untuk melakukan adaptasi secara instan terhadap teknologi yang digunakan oleh anak remajanya. Kurangnya pengetahuan orang tua terhadap situs jejaring sosial karena perbedaan persepsi yang ada diantara orang tua dan remaja (Jalaludin, 2015).

Selain itu orang tua yakni ayah dan ibu sebagai penanggung jawab utama atas anak harus menjalin kerjasama secara baik. Sehingga peran orang tua dalam mendidik anak dapat mencetak generasi cerdas serta berakhlak mulia di era digital seperti sekarang ini. Pendampingan ayah dan ibu bagi anak pada saat menggunakan gadgetnya dapat memberikan kesempatan bagi orang tua untuk membantu anaknya dalam menggunakan gadgetnya secara tepat (Bahri, 2019).

\section{Metode Penelitian}

Jenis atau rancangan penelitian ini adalah deskriptif analitik menggunakan metode survey dengan pendekatan korelasional yaitu penelitian yang sumber data dan informasi utamanya diperoleh dari responden sebagai sampel penelitian dengan menggunakan kuisioner atau angket sebagai instrumen pengumpulan data. Teknik pengambilan sampel menggunakan non probability sampling. Populasi dalam penelitian ini tidak diketahui jumlahnya sehingga pengambilan sampel dengan metode accidental sampling di media sosial. Sampel dalam penelitian ini sebanyak 228. Penelitian ini telah memenuhi kelayakan etik dari Komisi Etik Penelitian Kesehatan Sekolah Tinggi Ilmu Kesehatan Mahardika. Pengambilan data ini sebelumnya dilakukan persetujuan dengan menandatangani lembar informed consent. Data dikumpulkan dengan menggunakan kuesioner dan kemudian di olah dan dianalisis dengan menggunakan analisis univariat dan analisis bivariat yaitu analisis chi-square. 


\section{Hasil dan Pembahasan}

\section{A. Hasil Penelitian}

1. Karakteristik Responden

a. Usia Responden

\section{Tabel 1}

Distribusi Frekuensi Responden Remaja Pengguna Media Sosial Berdasarkan Umur

\begin{tabular}{ccc}
\hline Umur & $\mathbf{n}$ & $\mathbf{\%}$ \\
\hline $15-18$ tahun & 10 & 4,4 \\
\hline $19-21$ tahun & 99 & 43,4 \\
\hline $22-23$ tahun & 113 & 49,6 \\
\hline$>24$ tahun & 6 & 2,6 \\
\hline Total & $\mathbf{2 2 8}$ & $\mathbf{1 0 0}$
\end{tabular}

Dari hasil distribusi tabel 1 karakteristik responden menurut umur sebagian besar responden berusia 22 - 24 tahun dengan jumlah responden 113 responden $(49,6 \%)$.

b. Jenis Kelamin Responden

\section{Tabel 2}

Distribusi Frekuensi Responden Remaja Pengguna Media Sosial Berdasarkan Jenis Kelamin

\begin{tabular}{ccc}
\hline Jenis Kelamin & n & \% \\
\hline Perempuan & 176 & 77,2 \\
\hline Laki - laki & 52 & 22,8 \\
\hline Total & $\mathbf{2 2 8}$ & $\mathbf{1 0 0}$
\end{tabular}

Berdasarkan hasil dari distribusi tabel 2 karakteristik responden menurut jenis kelamin sebagian besar responden berjenis kelamin perempuan dengan jumlah 176 responden $(77,2 \%)$.

c. Suku Bangsa Responden

Tabel 3

Distribusi Frekuensi Responden Berdasarkan Suku Bangsa

\begin{tabular}{ccc}
\hline Suku Bangsa & $\mathbf{n}$ & $\mathbf{\%}$ \\
\hline Jawa & 115 & 50,4 \\
\hline Sunda & 75 & 4,4 \\
\hline Betawi & 10 & 4,4 \\
\hline Bugis & 5 & 2,1 \\
\hline Batak & 2 & 0,8 \\
\hline Melayu & 3 & 1,3 \\
\hline Timor & 3 & 1,3 \\
\hline Lainnya & 15 & 6,5 \\
\hline Total & $\mathbf{2 2 8}$ & $\mathbf{1 0 0}$
\end{tabular}


Berdasarkan tabel 3 distribusi karakteristik responden berdasarkan suku bangsa sebagian besar adalah Jawa dengan jumlah 115 responden $(50,4 \%)$.

d. Pekerjaan Orang Tua Responden

Tabel 4

Distribusi Frekuensi Orang Tua Berdasarkan Pekerjaan

\begin{tabular}{ccc}
\hline Pekerjaan & n & \% \\
\hline PNS & 18 & 7,9 \\
\hline Wiraswata & 206 & 90,4 \\
\hline Tidak Bekerja & 4 & 1,8 \\
\hline Total & $\mathbf{2 2 8}$ & $\mathbf{1 0 0}$
\end{tabular}

Sumber Data Primer, 2020

Berdasarkan tabel 4 distribusi karakteristik responden berdasarkan pekerjaan orang tua sebagian besar adalah wiraswasta dengan jumlah 206 responden $(90,4 \%)$.

e. Tingkat Pendidikan Orang Tua Responden

Tabel 5

Distribusi Frekuensi Orang Tua Berdasarkan Tingkat Pendidikan

\begin{tabular}{ccc}
\hline Pendidikan & n & \% \\
\hline SD & 54 & 23,7 \\
\hline SMP & 38 & 16,7 \\
\hline SMA & 94 & 41,2 \\
\hline Perguruan Tinggi & 39 & 17,1 \\
\hline Tidak Tamat Sekolah & 3 & 1,3 \\
\hline Total & $\mathbf{2 2 8}$ & 100
\end{tabular}

Berdasarkan tabel 5 maka dapat dilihat karakteristik responden tingkat pendidikan orang tua remaja pengguna media sosial sebagian besar adalah SMA dengan jumlah 94 responden $(41,2 \%)$.

2. Perilaku Hate Speech di Kalangan Remaja Pengguna Media Sosial Tabel 6

Distribusi Frekuensi Responden Remaja Pengguna Media Sosial Berdasarkan Tingkatan Kecenderungan Perilaku Hate Speech

\begin{tabular}{ccc}
\hline $\begin{array}{c}\text { Tingkatan Kecenderungan } \\
\text { Perilaku Hate Speech }\end{array}$ & $\mathbf{n}$ & $\mathbf{\%}$ \\
\hline Rendah & 107 & 46,9 \\
\hline Sedang & 81 & 35,9 \\
\hline Tinggi & 40 & 17,5 \\
\hline Tinggi & $\mathbf{2 2 8}$ & $\mathbf{1 0 0}$ \\
\hline
\end{tabular}

Sumber Data Primer, 2020 
Berdasarkan tabel 6 maka dapat dilihat presentasi dari remaja pengguna media sosial sebagian besar memiliki tingkat kecenderungan berperilaku hate speech dengan kategori rendah dengan jumlah 107 responden (46,9\%).

\section{Pola Asuh Orang Tua Remaja Pengguna Media Sosial Yang Melakukan} Hate Speech di Media Sosial

Tabel 7

Distribusi Frekuensi Berdasarkan Jenis Pola Asuh Orang Tua

\begin{tabular}{ccc}
\hline Pola Asuh & $\mathbf{n}$ & $\%$ \\
\hline Otoriter & $\mathbf{1 2 1}$ & 53,1 \\
\hline Demokratis & $\mathbf{5 7}$ & 25 \\
\hline Permisif & $\mathbf{5 0}$ & 21,9 \\
\hline Total & $\mathbf{2 2 8}$ & $\mathbf{1 0 0}$ \\
\hline
\end{tabular}

Sumber Data Primer, 2020

Berdasarkan tabel 7 maka dapat dilihat jenis pola asuh orang tua remaja pengguna media sosial sebagian besar adalah otoriter dengan jumlah 121 responden $(53,1 \%)$.

4. Hubungan Perilaku Hate Speech Di Media Sosial Dengan Pola Asuh Orang Tua Di Kalangan Remaja Pengguna Media Sosial

Tabel 8

Hubungan Perilaku Hate Speech Di Media Sosial Dengan Pola Asuh Orang Tua Di Kalangan Remaja Pengguna Media Sosial

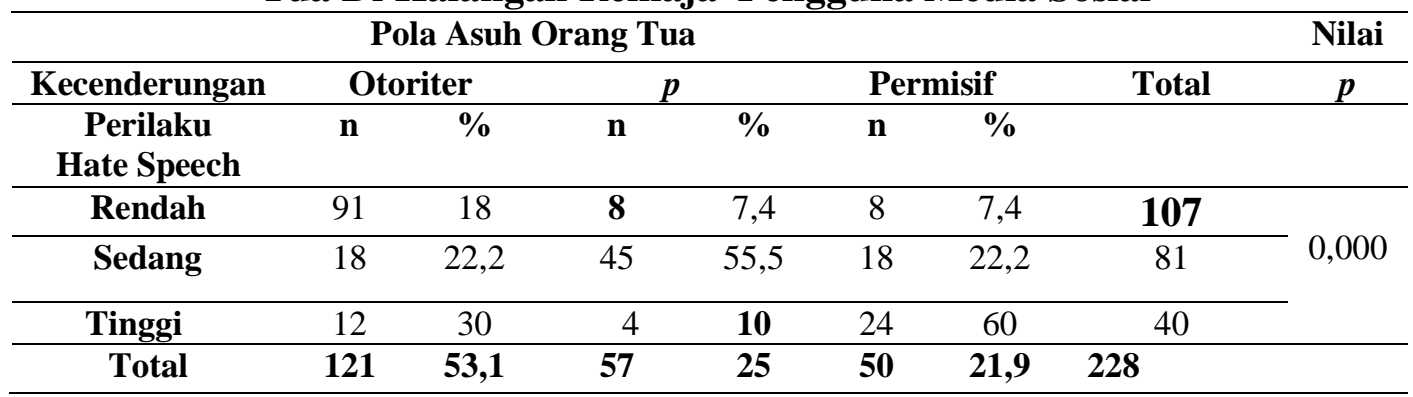

Berdasarkan tabel 8 tingkat kecenderungan remaja berperilaku hate speech di media sosial sebagian besar memiliki jenis pola asuh otoriter sebanyak 121 responden $(53,1 \%)$, kemudian yang memiliki jenis pola asuh demokratis sebanyak 57 responden (25\%), dan yang memiliki jenis pola asuh otoriter sebanyak 50 responden $(21,9 \%)$. Hasil uji statistik menggunakan uji Chi-Square dengan melihat nilai Pearson Chi-Square didapatkan $\mathrm{p}=0,000(\mathrm{p} \leq 0,05)$ maka $\mathrm{HO}=$ di tolak artinya terdapat hubungan antara perilaku hate speech di media sosial dengan pola asuh orang tua di kalangan remaja pengguna media sosial. 


\section{B. Pembahasan}

\section{Perilaku Hate Speech di Kalangan Remaja Pengguna Media Sosial}

Berdasarkan analisis data menunjukan responden dengan tingkat kecenderungan berperilaku hate speech kategori rendah sebanyak 107 responden (46,9\%), tingkat kecenderungan hate speech kategori sedang sebanyak 81 responden $(35,9 \%)$, dan tingkat kecenderungan hate speech kategori tinggi sebanyak 40 responden $(17,5 \%)$. Jadi berdasarkan dari hasil penelitian tersebut maka dapat dilihat presentasi dari remaja pengguna media sosial sebagian besar memiliki tingkat kecenderungan berperilaku hate speech kategori rendah dengan jumlah 107 responden (46,9\%).

Jika dilihat dari tingkatannya berdasarkan hasil penelitian yang telah dilakukan bahwa responden sebagian besar memiliki tingkat kecenderungn berperilaku hate speech rendah sebanyak 107 responden $(46,9 \%)$ dan kategori hate speech tinggi sebanyak 40 responden (17,5\%). Dilihat dari item kuesioner yang telah diisi oleh semua responden sebagian besar memilih item kuesioner dipoint tentang menghina suatu golongan dengan orientasi seksual yanag berbeda dengan kelompok mayoritas, yakni menghina golongan homoseksual. Selain itu item yang banyak dipilih reponden yaitu pada bagian tentang aliran keagamaan yang menyimpang.

Hasil penelitian ini sesuai dengan penelitian yang dilakukan (Cahyono, 2016) yang menyatakan bahwa deindividuasi berhubungan signifikan terhadap kecenderungan melakukan hate speech. Hal ini berarti semakin mewahnya fasilitas teknologi komunikasi di dunia maya di abad modern ini, ternyata tidak semakin mempermudah orang untuk meraih kenyamanan dan keamanan dalam berkomunikasi. Berbagai dampak negatif pun bermunculan sebagai imbas dari proses komunikasi yang terjadi di media sosial online, diantaranya yaitu kurangnya penghargaan terhadap sikap empati, simpati dan toleransi yang berujung kepada pengabaian terhadap nilai-nilai edukasi dan etika dalam berkomunikasi. Akibatnya dampak-dampak tersebut sangat berpengaruh bagi perkembangan komunikasi akademik mahasiswa dan pengembangan peradaban komunikasi di perguruan tinggi.

\section{Pola Asuh Orang Tua Remaja Penguna Media Sosial Yang Melakukan Hate Speech Di Media Sosial}

Berdasarkan analisis data menunjukan sebagian besar responden remaja pengguna media sosial memiliki jenis pola asuh otoriter sebanyak 121 responden $(53,1 \%)$, kemudian yang memiliki jenis pola asuh demokratis sebanyak 57 responden (25\%), dan yang memiliki jenis pola asuh permisif sebanyak 50 responden $(21,9 \%)$.

Hasil ini sejalan dengan hasil penelitian Ni Putu Ayu, dkk (2016) tentang hubungan antara kecenderungan pola asuh otoriter dengan gejala perilaku agresif pada remaja menunjukan bahwa adanya hubungan yang signifikan dan 
positif antara kecenderungan pola asuh otoriter dengan gejala perilaku agresif pada remaja, yakni sebagian besar remaja yang memiliki gejala berperilaku agresif memiliki pola asuh otoriter.

Pola asuh terdiri dari beberapa komponen, namun dalam kehidupan seharihari orang tua kadang menggunakan pola asuh yang variatif yang bersifat multidimensi. Hal ini disebabkan oleh situasi dan kondisi orang tua pada saat mendidik anak. Misalnya orang tua yang demokrasi bisa saja menunjukkan emosinya, mengancam, memberi hukuman dan lain-lain. Orang tua yang permisif bisa juga menunjukkan sikap restriktif, tidak memberi izin atau membiarkan anaknya mengambil pilihan semaunya, demikian juga dengan orang tua yang otoriter kadang bisa jadi lemah lembut, hangat, ramah, membolehkan menentukan pilihannya sendiri. Akan tetapi dengan pola asuh yang multidimensi ini ada satu kecenderungan kepada dimensi yang dominan, tergantung pada bagaimana anak atau tanggapan anak melalui persepsinya berdasarkan pengalaman selama diasuh atau diperlakukan oleh orang tuanya.

Pada beberapa kondisi sebenarnya orang tua perlu menerapkan pola asuh yang sesuai dengan kondisi, tidak selamanya orangtua harus menerapkan pola asuh secara otoriter, demokratis atau permisif secara terus menerus dan monoton. Hal ini dapat mengakibatkan hal yang tidak diinginkan terhadap anak. Seperti beberapa kasus yang terjadi pada anak yang yang suka membangkang atau melawan orang tua karena pola asuh orang tua yang lebih cenderung lembek, membiarkan anak sesuai dengan kemauannya, membebaskan anak tanpa kontrol, sehingga pada saat itu pola asuh otoriter harus diterapkan.

Selain itu banyak faktor yang mempengaruhi pola asuh orang tua, diantaranya tingkat pendidikan pendidikan orang tua, keyakinan, dan pola asuh yang didapatkan orang tua. Hal ini sejalan dengan penelitian yang telah dilakukan bahwa sebagian besar tingkat pendidikan orang tua responden adalah SMA sebanyak 94 responden $(41,2 \%)$.

\section{Hubungan Perilaku Hate Speech Di Media Sosial Dengan Pola Asuh Orang Tua Di Kalangan Remaja Pengguna Media Sosial}

Berdasarkan analisis data menunjukan sebagian besar responden remaja pengguna media sosial yang memiliki kecenderungan berperilaku hate speech tingkat rendah memiliki jenis pola asuh otoriter sebanyak 81 responden (85\%), yang memiliki kecenderungan berperilaku hate speech tingkat sedang memiliki jenis pola asuh demokratis senyak 45 responden $(55,5 \%)$, yang memiliki kecenderungan berperilaku hate speech tingkat tinggi memiliki jenis pola asuh permisif sebanyak 24 responden $(60 \%)$.

Tetapi berdasarkan jumlah keseluruhan sebagian besar menunjukan bahwa pada remaja dengan kecenderungan melakukan perilaku hate speech jenis pola asuh yang diterapkan sebagian besar adalah pola asuh otoriter dengan jumlah 121 responden $(53,1 \%)$. 
Berdasarkan hasil penelitian tersebut artinya ada hubungan antara perilaku hate speech yang dilakukan remaja di media sosial dengan pola asuh remaja tersebut, dimana pola asuh yang didapatkan akan menentukan bagaimana remaja tersebut berperilaku. Artinya peran orang tua sangat beerpengaruh terhadap pembentukan karakter anak tersebut.

Hasil penelitian ini sejalan dengan hasil penelitian (Ni putu Ayu (2016)) tentang hubungan antara kecenderungan pola asuh otoriter dengan gejala perilaku agresif pada remaja menunjukan bahwa adanya hubungan yang signifikan dan positif antara kecenderungan pola asuh otoriter dengan gejala perilaku agresif pada remaja, yakni sebagian besar remaja yang memiliki gejala berperilaku agresif memiliki pol asuh otoriter. Pengasuhan otoriter yang orang tua terapkan dalam mengasuh anak seringkali menggunakan hukuman fisik sebagai bentuk konsekuensi yang harus diterima oleh anak ketika melanggar aturan dan standar yang sudah diterapkan. Anak menganggap bahwa rumah adalah tempat dimana anak harus patuh akan standar orang tua, tempat dimana tidak adanya kesempatan untuk mengutarakan pendapat, dan rumah merupakan tempat resiko hukuman sangat besar diperoleh sehingga ketika berada di luar rumah lebih cenderung memunculkan perilaku agresif (Taylor, Peplau, \& Sears, 2009).

Tipe pengasuhan yang menekankan otoritas, membatasi adanya kendala yang penuh terhadap kehidupan anak, tidak memberi peluang anak untuk berdialog secara verbal, dan pemberian hukuman fisik maupun verbal sebagai bentuk pembelajaran atas kesalahan adalah pola pengasuhan otoritarian (otoriter). Pengasuhan secara otoriter yang membatasi anak dan memberikan hukuman berupa hukuman fisik ketika tidak mampu memenuhi standar yang orang tua tetapkan akan membuat anak marah dan kesal kepada orang tua tetapi tidak berani mengungkapkan kemarahannya sehingga anak akan melampiaskan kemarahannya tersebut di lingkungan luar (Sarwono \& Meinarno, 2009).

Berdasarkan hasil penelitian menunjukan bahwa secara proporsi sebagian besar responden dengan kecenderungan berperilaku hate speech dengan tingkatan tinggi memiliki pola asuh permisif sebanyak 24 responden (60\%). Berdasarkan Jurnal Dinas Kesehatan Republik Indonesia (2019) menjelaskan bahwa faktor-faktor yang mempengaruhi tingkah laku beresiko yang sering dilakukan remaja adalah faktor predisposisi lingkungan endogen seperti keadaan efektif mencari sensasi, agresifitas, perkembangan psikologis dan fisiologis yang tidak sinkron, kognisi pemicu perkembangan selama remaja, jenis kelamin, efek hormon, internalisasi keterlibatan teman sebaya, dan harga diri yang rendah. Faktor lingkungan eksogen seperti faktor keluarga, kurangnya pengetahuan tentang konsekuensi tingkah laku, tingkah laku teman sebaya, transisi sekolah, penyangkalan sosial dan tidak berespon terhadap lingkungan sekitar. Hal yang diungkapkan oleh (Zulkarnain (2020)) bahwa salah satu factor yang mempengaruhi perilaku hate speech adalah factor lingkungan, dimana 
lingkungan memberikan kesempatan untuk melakukan kejahatan dan lingkungan pergaulan yang memberi contoh dan teladan. Peneliti menambahkan jenis kelamin kedalam kuesioner dan sebagian besar reponden adalah perempuan. Sesuai dengan penelitian yang telah dilakukan menunjukan bahwa reponden sebagian besar adalah remaja perempuan sebanyak 176 responden (77,2\%). Hasil penelitian ini sejalan dengan penelitian (Duggan \& Benner (2013). bahwa dampak buruk yang ditimbulkan dari penggunaan media sosial ini lebih banyak menimpa perempuan karena kehidupannya banyak dipengaruhi oleh media sosial dan perempuan lebih aktif di media sosial dibanding laki-laki.

\section{Kesimpulan}

Penelitian ini mengidentifikasi adanya hubungan perilaku hate speech di media sosial dengan pola asuh orang tua di kalangan remaja pengguna media sosial dengan $\mathrm{p}$ value $=0.000$. Hasil penelitian ini menunjukkan bahwa pola asuh otoriter dapat membatasi kebebasan anak dan memberikan hukuman berupa hukuman fisik ketika tidak mampu memenuhi standar yang orang tua tetapkan akan membuat anak menjadi marah dan kesal kepada orang tua, tetapi tidak berani mengungkapkan kemarahannya. Sehingga, anak akan melampiaskan kemarahannya tersebut di lingkungan luar. Faktor lainnya yang mempengaruhi tingkah laku hate speech diantaranya adalah faktor predisposisi lingkungan endogen seperti keadaan efektif mencari sensasi, agresifitas, perkembangan psikologis dan fisiologis yang tidak sinkron, kognisi pemicu perkembangan selama remaja, jenis kelamin, efek hormon, internalisasi keterlibatan teman sebaya, dan harga diri yang rendah. Faktor lingkungan eksogen seperti faktor keluarga, kurangnya pengetahuan tentang konsekuensi tingkah laku, tingkah laku teman sebaya, transisi sekolah, penyangkalan sosial dan tidak berespon terhadap lingkungan sekitar. 


\section{BIBLIOGRAFI}

Akbar, Rusdi, Pilcher, Robyn Ann, \& Perrin, Brian. (2015). Implementing performance measurement systems. Qualitative Research in Accounting \& Management.

Astuti Firmaina (2019). Perilaku Hatespeech Pada Remaja di media Sosial Instagram. Universitas Muhammadiyah. Surakarta.

Bahri. (2019). Pola Komunikasi OrangTua dan Anak dalam Keluarga (sebuahperspektif Pendidikan Islam). Jakarta: Rineka Cipta.

Briawan, Dodik, \& Herawati, Tin. (2008). Peran stimulasi orangtua terhadap perkembangan anak balita keluarga miskin. Jurnal Ilmu Keluarga \& Konsumen, $1(1), 63-76$.

Cahyono, Anang Sugeng. (2016). Pengaruh media sosial terhadap perubahan sosial masyarakat di Indonesia. Jurnal Publiciana, 9(1), 140-157.

Duggan M. Brenner J. (2013). Report, The Demographics of Social Media Users 2012. Washington DC: Pew Internet \& American Life Project.

Judhita, C. (2017). Hate speech di Media Online: Kasus Pilkada Dki Jakarta 2017. Jakarta

Rakhmat, Jalaludin. (2015). Psikologi Komunikasi. Bandung: PT. Remaja Rosdakarya Offset.

Manusia, Komisi Nasional Hak Asasi. (2015). Buku Saku Penanganan Ujaran Kebencian (Hate Speech). Jakarta: KOMNAS HAM.

Ni Putu Ayu Resitha Dewi. (2016). Hubungan Antara Kecenderungan Pola Asuh Otoriter (Authoritarian Parenting Style) dengan Gejala Perilaku Agresif Pada Remaja. Jurnal Psikologi Udayana

Permono, Hendarti. (2013). Peran orangtua dalam optimalisasi tumbuh kembang anak untuk membangun karakter anak usia dini.

Sarwono, Sarlito W., \& Meinarno, Eko A. (2009). Psikologi Sosial. Jakarta: Salemba Humanika, 77.

Taylor, S. E., Peplau, L. A., \& Sears, D. O. (2009). Social Psychology (Terjemahan: Tri Wibowo). Jakarta: Kencana Prenada Media Group.

World Health Organization (WHO). (2014). .https://www.who.int/maternal_child_adolescent/topics/adolescence/development/e n/-Diakses Desember 2019.

Zulkarnain (2020). Ujaran Kebencian (Hate Speech) Di Masyarakat Dalam Kajian Theologi. Studia Sosia Religia. Volume 3 Nomor 1, Januari-Juni 2020 EISSN;2622-2019 http://jurnal.uinsu.ac.id/index.php/ssr 